\title{
The Influence of HR, IT, and Market Knowledge Competencies on the Performance of HR Managers in Food Exporting Companies in Thailand
}

\author{
Sarunya Lertputtarak \\ Graduate School of Commerce, Burapha University \\ 169 Longhard Bangsaen Road, A.Muang, Chonburi 20131, Thailand \\ E-mail: sarunya_L@hotmail.com
}

Received: August 11, 2011

Accepted: September 28, 2011

Published: January 1, 2012

doi:10.5539/ibr.v5n1p87

URL: http://dx.doi.org/10.5539/ibr.v5n1p87

Sponsoring information: Graduate School of Commerce, Burapha University

\begin{abstract}
The main purposes are to study the characteristics of HR managers and their organizations as well as to examine their level of HR, IT, and market knowledge competencies, and also study the influence of HR, IT, and market knowledge competencies on performance. The samples of $1000 \mathrm{HR}$ managers companies were selected by random sampling from 2270 food export companies listed in the Thailand's Exporters Directory. There were 374 questionnaires which were used for data analysis. The results showed that HR managers who have different personal data and organizational characteristics have significant differences in HR, IT, and market knowledge competencies at a significance level of 0.05 . HR and market knowledge competencies can influence HR and organizational performance, whereas IT competencies cannot influence HR and organizational performance.
\end{abstract}

Keywords: Human resource competencies, Marketing knowledge competencies, IT competencies, Performance

\section{Introduction}

Businesses are adopting a global strategy and taking a global view of their operations. Organizations within contemporary business environments are facing intense competitive situations. Values, competitive advantages, and focus are required in order to succeed in the market place and appropriate and effective strategies are essential. The strategies should guide efforts in any part of the world and utilize an information system capable of monitoring the globe for opportunities and threats. Therefore, virtual organizations are eager to provide a flexible, cohesive and synergistic business necessary to operate successfully in the current business climate (Introna, 2001).

The food industry is one of the most important industries in Thailand. In 2009, the value of Thailand food exports was 778,056 million baht or $13.3 \%$ of total export products, $8.5 \%$ of GDP or $2.3 \%$ of total world food exports (Food Intelligence Center, 2010). The main products for export are shrimp, canned tuna, chicken, rice, canned pineapple, and sweet corn. However, there was a slightly lower rate of increase of food exports in late 2009 because of the political crisis. Moreover, the producers are currently faced with higher production costs, an unstable world economy, changes in petrol price, and an unstable Thai baht, therefore the producers have to review their production and management policies (The Federation of Thai Industry, 2010).

In a continuously changing environment it has become impossible to manage successfully without sustained personal development. Managers of organizations face the globalization of business, rapid technological changes, continual reorganizing and competence-based competition (Viitala, 2005). Therefore, managers' competencies need to be renewed on a regular basis.

The role of human resources (HR) is becoming more important for business accomplishment (Mohrman \& Lawler, 1997; Wright, Candner, Moynihan, \& Allen, 2005). Davenport (1999) stated that the value of human capital is increasing, that the tangible assets account for $62 \%$ of market value. But after ten years, hard assets account for $32 \%$ of market value, while intangible assets including human capital account for as much as $80 \%$ of the value of an organization (Hogan et al., 2002). This shows that organizational outcomes are increasingly affected by the knowledge, skills, and abilities of qualified employees. 
Therefore to develop the competencies for the HR manager is also an essential task. The results of this study can develop and enhance the knowledge of HR managers so as to improve their skills in order to perform their work well and also the educational institutions can utilize the results of this study for conducting suitable courses to match the skills that HR managers require.

\section{Review of Literature}

\subsection{Resource-Based Theory on Human Resource Management}

In a complex society, human resource theorists have drawn heavily on resource-based logic to examine the impact of human resources and HR policies on firm performance (Barney \& Wright, 1998 cited in Barney \& Clark, 2007), especially on cost and quality in manufacturing (MacDuffie, 1995 cited in Barney \& Clark, 2007). HR practices can influence the creation of significant firm specific human capital investment (Huselid \& Becker, 1997 cited in Barney \& Clark, 2007) and improve firm performance (Delaney and Huselid, 1996 cited in Barney \& Clark, 2007).

Huselid (1995 cited in Barney \& Clark, 2007) observed that investment in high performance work practices reflected in lower employee turnover and greater productivity and financial performance. HR involvement in strategy and perception of HR effectiveness links between strong employee commitment and generic strategies (Wright, McCormick \& Sherman, 1998).

\subsection{HR Competencies}

HR competencies were the set of characteristics contributing to effective HR performance enabling an organization to achieve its business strategies in a competitive market. It is suggested that the competency level of the HR manager has an influence on whether he/ she can get into the executive board chamber (Truss \& Gratton, 1994 cited in Selmer \& Chiu, 2004).

Ulrich (1997) surveyed 3000 HR professionals, consultants, line executives and academicians and found that line executives thought that computer literacy was the most critical HR competence, while academicians argued that a broad knowledge of and having a vision for HR were the most important issues whereas consultants believed that ability to change things was the most important.

From the literature review about HR competencies, this study follows Jian, Pual, Minston and Patrick (2006) because their research studied HR managers' competencies in an Asian country. They studied the relationship between HR competencies and HR effectiveness as perceived by line manager and employees within 39 surveyed Taiwanese high-tech firms. The HR competencies in their study were:

\subsubsection{Knowledge of Business}

company's business model, profit chain, organizational structure, the industry, company's short and long term strategies, the functional roles and responsibilities of other departments within this company, knowledge about company's external environment and overall company's business operation.

\subsubsection{HR Functional Expertise}

HR functional roles such as recruiting, promoting and placing appropriate people to fit the job description and requirement, career planning services for employees, develop and organize training, develop competitive compensation system, design a non-financial motivational system, develop performance evaluation system, and etc.

\subsubsection{Managing Change}

HR professionals can use up-to-date methods and technologies to accomplish company's goals, can adapt HR practices and services in response to change for internal and external conditions, can use information data as a source to influence colleagues, can take a proactive role in bringing about change, can establish relationships necessary for change, and whether HR department has strong skills to cope with various changes within the organization.

\subsection{IT Competencies}

IT competencies in this study means degree of computer-based technical expertise, knowledge of new computer-based innovations, and the knowledge to develop and maintain computer-based communication links with customers (Tippins \& Sohi, 2003).

\subsection{Market Knowledge Competencies}

$\mathrm{Li}$ and Calantone (1998) classified market knowledge competencies into four activities: market scanning, market information transmission, market information interpretation, and market knowledge utilization. 
Market Scanning is defined as an information acquiring and gathering activity that involves both formal and informal searches about the marketplace (Aguilar 1967, Miller and Friesen 1982; Starbuck 1976). The market scanning behavior may vary according to the breadth/narrowness and formal/informal acquisition of information about the marketplace (Aguilar 1967; Daft and Weick 1984) by examining customer needs and wants, competitors, retailers, distributors, suppliers, technology, demography, economy, and other environmental forces that may affect firm performance (Day, 1994; Kohli and Jaworski, 1990; Sinkula, 1994; Slater and Narver, 1995).

The role of market information transmission activity in creating competitive advantage has been emphasized by marketing scholars (Maltz and Kohli, 1996; Sinkula, Baker \& Noordewier, 1997; Slater \& Narver, 1995). Market information transmission is defined as the extent to which market information is diffused among relevant users within a given organization ranging from transmitted information changes across customers, competitors, retailers/ distributors, suppliers, and market trends (Beyer \& Trice, 1982; Jaworski \& Kohli, 1993; Moorman, 1995).

Market Information Interpretation is the distinctive feature of the interpretation activity which is the conversion of information into knowledge and the creation of shared understanding among managers (Weick and Roberts, 1993). Data represents individual facts and alone is meaningless. Data becomes information when the receiver decides whether the data is really information or just noise, based on relevancy to a work at hand and capacity to fulfill a goal.

Market Knowledge Utilization, which implies action-oriented use (Menon \& Varadarajan, 1992), refers to the extent to which an organization directly applies market knowledge to influence marketing strategy-related actions (Moorman, 1995). Market knowledge can be utilized in decision-making, implementation, and evaluation of marketing decisions (Moorman, 1995).

\subsection{HR Managers' Performance}

This study measures human resource competencies by selecting the measurement of Gomes, Yasin and Lisboa (2006) by comparing the increase/ decrease rate of each of the components because the HR manager can directly evaluate their work by themselves. Gomes, Yasin and Lisboa (2006) measured human resource performance by examining whether managers can perform (1) equal employee opportunity, (2) employee involvement, (3) employee training, (4) profit share or other incentive plans, (5) insurance plans (life, health and education), (6) employee turnover, (7) absentee rates, (8) safety record, and, (9) labor management relations.

\subsection{Organizational Performance}

HR performance of this study will follow Huselid (1995) as his measurement covers both financial and non-financial measurement including: 1 . The perceived organizational performance: quality of products, development of new products, ability to attract essential employees, ability to retain essential employees, satisfaction of customers, relations between management and other employees, relations among employees in general. 2. The perceived market performance: growth of sales, profitability, market share. 3. The perceived employee skills: staff selectivity, training effectiveness, employee motivation, structure of job and work, and internal labor market.

\subsection{Conceptual Framework}

Insert Figure 1 Here

\section{Methodology}

The questionnaires will be distributed to 1,000 respondents selected by simple random sampling from a total of 2 270 respondents who are HR managers in food export companies from Thailand's exporters directory (Department of Export Promotion, 2010). The data collection method is a questionnaire survey by mail and followed up by a telephone call. There were 398 returned questionnaires (response rate 39.80\%) and 64 unreturned questionnaires (6.4\%). There were 374 questionnaires that could be used for data analysis.

The questionnaires were divided into 5 sections: Section 1 contained the respondents' personal and organizational data. All the questions were in the form of a check list using both nominal and ordinal scales. Section 2 was about the current level of expertise in HR competencies that was developed from Jian, et al. (2006) in the form of a Likert scale 5 rating scale. Section 3 was about the current level of expertise in IT competencies that was developed from Tippins and Sohi (2003) in the form of a Likert scale 5 rating scale. Section 4 was about the current level of expertise in market knowledge competencies that was in the form of a Likert scale 5 rating scale. Section 5 contained two parts: 1) HR performance is measured by asking respondents to assess their business unit's performance by comparing performance between 2008 and 2009. The questionnaire was developed from Gomes, Yasin, \& Lisboa (2006). 2) Organizational performance: the questionnaire was developed from Huselid (1995). Relative performance on each dimension was measured by asking respondents to assess their organizational 
performance relative to that of major competitors (Vorhies, Harker, Rao, 1999; Huang, Chen, \& Yien, 2007). Five point Likert-type scales were used.

Results were; reliability analysis of HR competencies $\alpha=0.952$, IT competencies $\alpha=0.964$, Marketing knowledge competencies $\alpha=0.917$, HR performance $\alpha=0.871$, and organizational performance $\alpha=0.907$.

\section{Results}

\subsection{Profiles of Respondents and Their Organizations}

The majority of respondents were female with 189 persons (50.5\%), age ranging from 41-50 years old (38\%), the predominant level of education was bachelor degree at 196 persons $(52.4 \%), 113$ persons $(30.2 \%)$ had 6-10 years working experience as HR managers, 157 persons (42\%) had a monthly income between $20001-50000$ baht and 263 persons (30.3\%) were responsible for several management duties including HR.

The majority of the respondents' organizations at 240 companies $(64.2 \%)$ had authorized capital less than 2 million baht, 322 companies $(86.10 \%)$ were Thai, 139 companies $(37.20 \%)$ had more than 500 workers, and 124 companies $(33.10 \%)$ produced canned food/foods in containers.

\subsection{Descriptive Analysis of Variables}

The HR competencies of respondents were at a moderate level $(\bar{X}=3.45)$, IT competencies were at a moderate level $(\bar{X}=3.28)$, market knowledge competencies were at a moderate level too $(\bar{X}=3.45)$. HR performance in 2009 can be performed better than in $2008(\bar{X}=3.37)$ and organizational performance in 2009 can be performed better than competitors $(\overline{\mathrm{X}}=3.30)$.

\subsection{Results of Hypothesis testing}

Hypothesis 1: HR managers who have different personal data have a significant difference in HR competencies

\section{Insert Table 1 Here}

Tables 1 shows HR managers who have different personal data have a significant difference in HR competencies at a level of significance of 0.05 .

Hypothesis 2: HR managers who work with different organizational characteristics have a significant difference in HR competencies

Insert Table 2 Here

Table 2 shows HR managers that work in organizations which have different authorized capital and numbers of workers and type of main product have a significant difference in HR competencies at a level of significance of 0.05 . While HR managers who work in organizations that have a different nationality have no significant difference in HR competencies.

Hypothesis 3: HR managers who have different personal data have a significant difference in IT competencies Insert Table 3 Here

Table 3 shows HR managers who have different genders, ages, levels of education and monthly incomes have a significant difference in IT competencies at a level of significance of 0.05 . While HR managers who have different working experience and task responsibilities have no significant difference in IT competencies.

Hypothesis 4: HR managers who work in different organizational characteristics have a significant difference in IT competencies

\section{Insert Table 4 Here}

Table 4 shows HR managers that work in organizations which have different authorized capital, nationality and number of workers have no significant difference in IT competencies at a level of significance of 0.05 . While HR managers who work in organizations which have different types of main products have a significant difference in IT competencies.

Hypothesis 5: HR managers who have different personal data have significant differences in market knowledge competencies.

\section{Insert Table 5 Here}

Table 5 shows HR managers who have different genders, ages, working experience and monthly incomes have a significant difference in market knowledge competencies at a level of significance of 0.05 . While HR managers who 
have different levels of education and task responsibilities have no significant difference in market knowledge competencies.

Hypothesis 6: HR managers who work in different organizational characteristics have a significant difference in market knowledge competencies

Insert Table 6 Here

Table 6 shows HR managers who work in organizations which have different authorized capital, numbers of workers and types of main products have no significant difference in market knowledge competencies. HR managers who work in an organization that has a different nationality have a significant difference in market knowledge competencies.

Hypothesis 7: HR, IT, and market knowledge competencies can influence HR performance.

Insert Table 7 Here

Tables 7 and 8 show the hypothesis testing by using Stepwise Multiple Linear Regression, and the results show that HR competencies and market knowledge competencies can influence HR performance. IT competencies cannot influence HR performance. The regression model can forecast the change in the dependent variable at $34.2 \%$.

The Non-standardized model: HR performance $=1.732+0.399$ (HR competencies) ${ }^{*}+0.077$ (Market knowledge competencies)* +0.055 (IT competencies) $+\mathrm{e}$

Hypothesis 8: HR, IT, and market knowledge competencies can influence organizational performance.

Insert Table 8 Here

In solving the hypothesis by using Stepwise Multiple Linear Regression the results show that market knowledge competencies and HR competencies can influence organizational performance. IT competencies cannot influence organizational performance. The regression model can forecast the change in the dependent variable at $21.0 \%$.

The Non-standardized model: Organizational performance $=1.327+0.397$ (Market knowledge competencies)* +0.176 (HR competencies) ${ }^{*}+0.041$ (IT competencies) $+\mathrm{e}$

\section{Discussion}

HR competencies were the set of characteristics contributing to effective HR performance enabling an organization to achieve its business strategies in a competitive market (Mohrman \& Lawler, 1997; Wright, Candner, Moynihan, \& Allen, 2005). The results of this study show that HR competencies of respondents were only at a moderate level. On examining each HR competency component which had knowledge of business at a high level but the HR functional expertise competency and managing change competency were at a moderate level.

After testing the hypotheses comparing the HR competencies from the difference in respondents' personal data, the results showed that females have more HR competencies than males. Managers between the ages of 31-40 years old have more HR competencies than managers of the other age groups. The managers who have bachelor degrees have more HR competencies than managers who have master degrees and below bachelor degrees. There might be other factors in their personal characteristics that affect their competencies, such as working experience, as the results also revealed that managers who have worked for 1-10 years have more HR competencies than managers who have less working experience and HR managers who performed only HR tasks have more HR competencies than managers who have to not only perform HR tasks but also have to be responsible for other tasks.

Furthermore, HR managers who worked in organizations that have higher authorized capital and numbers of workers have more HR companies. When comparing Thai and foreign organizations, Thai companies have more HR competencies. Lastly, managers who worked in organizations whose main products were chilled/ frozen foods and semi-processed foods from animals have higher HR competencies. On the other hand, managers who work in organizations which have authorized capital less than 2 million baht, foreign nationality, less than 50 workers and produce semi-processed food from plants and canned food/ food in containers have the lowest HR competencies.

Comparing IT competencies from the difference in respondents' personal data, the results showed that female managers have more IT competencies than males. The results are the same as HR competencies for age, as managers whose ages are between 31-40 years old have the highest IT competencies, while 21-30 year old managers have the lowest level of competencies. The managers who have bachelor degrees have more HR competencies than managers who have master degrees and below bachelor degrees. Managers who have working experience of 16-20 years have more IT competencies than managers who have less working experience and also those who work for more than 20 years. Managers who earn more income have more IT competencies. Nevertheless, managers who perform only HR tasks and persons who have to manage other tasks have equal IT competencies. 
Managers who work in organizations that have authorized capital of 2 million-100 million baht, work in Thai companies, have less than 50 workers persons and produce semi-processed foods from animals have the highest IT competencies. In contrast, managers in organizations that have authorized capital of more than 100 million baht, work in joint ventures between Thai and foreign companies, have less than 50 workers and produce canned food/ foods in containers have the lowest IT competencies.

Comparing market knowledge competencies from the difference in respondents' personal data, the results showed that female managers have more market knowledge competencies than males. Managers aged 31-40 years old have more market knowledge competencies than managers of other ages. The managers who have master degrees have more market knowledge competencies than managers who have lower than master degrees. Managers who have worked for more than 20 years have more market knowledge competencies than managers who have less working experience. Nevertheless, managers who perform only HR tasks and persons who have to manage other tasks have equal market knowledge competencies.

Managers who work in organizations that have authorized capital of 2 million-100 million baht, work in Thai companies, have more than 200 workers and produce semi-processed foods from animals have the highest market knowledge competencies. In contrast, managers in organizations that have authorized capital of more than 100 million baht, work in joint ventures between Thai and foreign companies, have 50-200 workers and produce chilled/ frozen foods and semi-processed foods from plants have the lowest IT competencies.

HR practices can influence and improve firm performance (Delaney and Huselid, 1996, cited in Barney, 2007). According to results of this study, the HR performance in 2009 was better than in 2008 and the organizational performance in 2009 was better than the competitors. Testing multiple regression analysis found that HR and marketing competencies can influence HR and organizational performance. Huselid (1995, cited in Barney, 2007) observed that investment in high performance work practices reflected in lower employee turnover, greater productivity and financial performance. HR involvement in strategy and perception of HR effectiveness (Wright, McCormick, \& Sherman, 1998), showed links between strong employee commitment and generic strategies (Lee \& Miller, 1999). Marketing knowledge can influence firm performance as well. Luigi and Kwaku (2007) studied market knowledge dimensions and cross-functional collaboration thus examining the different routes to product innovation performance. The results from a double-informant survey of high-tech firms in China show that market knowledge breadth, depth, and specificity positively influence product innovation performance. Therefore, in order to increase HR performance and organizational performance, firms should place emphasis on developing HR and marketing knowledge competencies for HR managers.

However, the results of this study showed that IT competencies cannot influence HR and organizational performance. These results occurred in Thailand because IT competencies and equipment are underdeveloped, and many organizations did not pay attention to getting HR managers to learn more IT skills. But from previous research, IT competencies are important, Ravichandran (2007) studied IT competencies, innovation capacity, organizational agility, performance impact and the moderating effects of environmental characteristics. The results showed that firms with superior information system capabilities coupled with an aggressive IT investment orientation created digital options that enable firms to be agile. The innovativeness and the tight coupling of the firm's innovation efforts with the core organization have a positive relationship with organizational agility. Finally, organizational agility has a strong positive impact on firm performance.

\section{Conclusions and Recommendation}

\subsection{Conclusions and Recommendation}

The results show that market knowledge competencies and HR competencies can influence organizational performance but IT competencies cannot influence organizational performance. Although HR competencies can influence firm performance, HR managers have only moderate HR competencies. Therefore, companies should take responsibility to develop the skills of HR managers. First of all, managers have less knowledge about the companies' business, organizational structure and profit chain. Next, functional expertise competency, such as how to develop a competitive compensation system with line managers to improve on recruiting and retention objectives, offer career planning services to employees in need, and to develop and organize training programs that meet the needs of other functional departments. Finally, developing managing-change competency by increasing knowledge about a proactive role in bringing about change, how to use information data as a source to influence colleagues, and how to adapt HR practices and service in response to change in external conditions such as competitor retaliation, labor laws and regulation and market situations.

HR managers should develop their market knowledge competencies in order to gain more advantage from marketing data derived from research and other sources of information. They should spend time discussing about future 
customer needs with other functional departments. Then, develop the expertise to generate explanations for the given market information. Finally, provide a clear direction to other departments regarding their role in implementation.

IT competencies did not influence organizational performance in this study, but the previous studies stated the important roles of IT competencies. Companies should pay attention to develop IT competencies for HR managers as well by providing and maintaining a climate that nurtures IT to be the best, increase expertise to plan for security control, standards compliance, disaster recovery, establish an effective and flexible IT planning process, develop a robust IT plan, etc.

Organizations should strive to build a climate of organizational learning by creating the infrastructure for learning and the applications of learning.

Moreover, educational administrators should take the responsibility to cultivate prospective human resource and HRD professionals in formal education programs. The teaching courses should develop and support the requirements of HR managers and their employers. HR managers should have the opportunity to learn not only about HR functions but also other areas of management, such as marketing and IT knowledge. The other competencies that are essential for HR managers should be added into educational programs because HR managers should work to serve as effective members of the management team. They need to perform their functions in a way that takes into account the financial, strategic and technological goals of the institution.

\subsection{Recommendations for Further Study}

This study was limited to the HR managers on the list of Thailand's Exporters Directory. Further investigation might be of value to explore other types of organizations on a wider base such as companies from other industries or non-profit or government organizations.

A study should compare the perceptions identified in Thailand with other countries in South East Asia.

The other competencies should be added into further studies, because HR managers are now performing multi-tasks in cross functions of departments, and if possible, it should rank the roles and competencies required by HR managers, as each business and industry has its own needs and need assessments in order to train them in the proper direction and also bring benefits to designing curriculum in educational institutions.

\section{References}

Aguilar, F. J. (1967). Scanning the business environment. New York: Macmillan.

Barnay, J. B., \& Clark, D. N. (2007). Resource-based theory: Creating and sustaining competitive advantage. New York: Oxford University Press.

Barney, J. B., \& Wright, P. M. (1998). On becoming a strategic partner: The role of human resources in gaining competitive advantage. Human Resource Management, 37, 31-46. http://dx.doi.org/10.1002/(SICI)1099-050X(199821)37:1<31::AID-HRM4>3.0.CO;2-W

Beyer, J. M., \& Trice M. H. (1982). The utilization process: A conceptual framework and synthesis of empirical findings. Administrative Science Quarterly, 27(4), 591-622. http://dx.doi.org/10.2307/2392533

Daft, R. L., \& Weick, K. E. (1984). Toward a model of organizations as interpretation systems. Academy of Management Review, 9(2), 284-95. http://dx.doi.org/10.2307/258441

Davenport, T. (1999). Human Capital: what it is and why people invest in it. San Francisco: Jossey-Bass.

Day, G. S. (1994). The capabilities of market-driven organizations. Journal of Marketing, 58(4), 37-52. http://dx.doi.org/10.2307/1251915

Delaney, J. Y., \& Huselid, M. A. (1996). The impact of human resource management practices on perceptions of organizational performance. Academy of Managerial Journal, 39(4), 949- 969. http://dx.doi.org/10.2307/256718

Food Intelligence Center. (2010). The structure of food industry in Thailand. [Online] Available: http://fic.nfi.or.th/th/thaifood/default.asp. (May 28, 2010)

Gomes, F. C., Yasin, M. M., \& Lisboa, V. J. (2006). Performance measurement practices in manufacturing firms: empirical investigation. Journal of Manufacturing Technology Management, 17(2), 144-167. http://dx.doi.org/10.1108/17410380610642241

Han, J., Chou, P., Chao, M., \& Wright, P. M. (2006). The HR competencies-HR effectiveness link: A study in Taiwanese high-tech companies. Human Resource Management. 45(3), 391-406. doi:10.1002/hrm.20114, http://dx.doi.org/10.1002/hrm.20114 
Hogan, J., Lehmann, D., Merino, M., Srivastave, R., Thomas, J., \& Verhoef, P. (2002). Linking customer assets to financial performance. Journal of Service Research, 5(1), 26-38. http://dx.doi.org/10.1177/1094670502005001004

Huang, Mu-Jung, Chen, Mu-Jen, \& Yien, K. (2007). Comparing with your main competitor: The single most important task of knowledge management performance measurement. Journal of Information Science, 33(4), 416-434. http://dx.doi.org/10.1177/0165551506076217

Huselid, M. A. (1995). The impact of human resource management practices on turnover, productivity, and corporate financial performance. Academy of Management Journal, 378, 635-372. http://dx.doi.org/10.2307/256741

Huselid, M. A., \& Backer, B. E. (1997). The impact of high performance work systems, implementation effectiveness, and alignment with strategy on shareholder wealth. Academy of Management Best Papers Proceedings, 8(1), 144-148. http://dx.doi.org/10.5465/AMBPP.1997.4981101

Introna, L. (2001). Defining the virtual organization, in Barnes, S., Hunt, B. 2001. Oxford: Butterworth-Heinemann, 143-152.

Jaworski, B. J., \& Ajay K. K. (1993). Market orientation: Antecedents and consequences. Journal of Marketing, 57(3), 53-70. http://dx.doi.org/10.2307/1251854

Kohli, A. K., \& Jawarski J. B. (1990). Market orientation: The construct research propositions, and managerial implications. Journal of Marketing, 54(2), 1-18. http://dx.doi.org/10.2307/1251866

Li, T., \& Calantone, J. R. (1998). The impact of market knowledge competence on new product advantage: Conceptualization and empirical examination. Journal of Marketing, 62(4), 13-29. http://dx.doi.org/10.2307/1252284.

Luigi, M. De Luca, \& Kwaku, A. G. (2007). Market knowledge dimensions and cross-functional collaboration: Examining the different routes to product innovation performance. Journal of Marketing, 71(1), 95-112. http://dx.doi.org/10.1509/jmkg.71.1.95

MacDuffie, J. (1995). Human resource bundles and manufacturing performance: organizational logic and flexible production systems in the world auto industry. Industrial and Labor Relations Review, 49, 197-221. http://dx.doi.org/10.2307/2524483

Maltz, E., \& Kohli, A. K. (1996). Market intelligence dissemination across functional boundaries. Journal of Marketing Research, 33(1), 47-61. http://dx.doi.org/10.2307/3152012

Menon, A., \& Varadarajan P. R. (1992). A model of marketing knowledge use within firms. Journal of Marketing, 56(4), 53-71. http://dx.doi.org/10.2307/1251986

Miller, D., \& Friesen, P. H. (1982). Innovation in conservative and entrepreneurial firms: Two models of strategic momentum. Strategic Management Journal, 3(1), 1-25. http://dx.doi.org/10.1002/smj.4250030102

Mohrman, S. A., \& Lawler, E. E. (1997). Transforming the human resource function. New York: Wiley. http://dx.doi.org/10.1002/(SICI)1099-050X(199721)36:1<157::AID-HRM25>3.3.CO;2-1.

Moorman, C. (1995). Organizational market information processes: Cultural antecedents and new product outcomes. Journal of Marketing Research, 32(3), 318-335. http://dx.doi.org/10.2307/3151984

Ravichandran, T. (2007). IT competencies, innovation capacity and organizational agility: Performance impact and the moderating effects of environmental characteristics. [Online] Available: http://www.citi.uconn.edu/cist07/7b.pdf.

Selmer, J., \& Chiu, R. (2004). Required human resource competencies in the future: A framework in developing HR executives in Hong Kong. Journal of World Business, 38, 324-336. http://dx.doi.org/10.1016/j.jwb.2004.08.001.

Sinkula, J. M. (1994). Market information processing and organizational learning. Journal of marketing, 58(1), 35-45., http://dx.doi.org/10.2307/1252249

Sinkula, J. M., Baker, W. E., \& Noordewier, T. (1997). A framework for market-based organizational learning: Linking values, knowledge, and behavior. Journal of the Academy of Marketing Science, 25(4), 305-18. http://dx.doi.org/10.1177/0092070397254003

Slater, S. F., \& Narver, J. C. (1995). Market orientation and the learning organization. Journal of Marketing, 59(3), 63-74. http://dx.doi.org/10.2307/1252120

Starbuck, W. H. (1976). Organizations and their environments. Chicago: Rand McNally. 
The Federation of Thai Industry. (2010). Summary of food industry and its export trend of Thailand in year 2009. [Online] Available: http://www.fti.or.th/2008/thai/ftitechnicalsubdetail.aspx?id=48.

Tippins, J. M., \& Sohi, R. S. (2003). IT competencies and firm performance: IS organizational learning a missing link? Strategic Management Journal, 24, 745-761. http://dx.doi.org/10.1002/smj.337

Truss, C, \& Gratton, L. (1994). Strategic human resource management: A conceptual approach. International Journal of Human Resource Management, 5(3), 663-686. http://dx.doi.org/10.1080/09585199400000053

Ulrich, D. (1997). Human resource champions. USA: Harvard Business School Press.

Viitala, R. (2005). Perceived development needs of managers compared to an integrated management competency model. Journal of Workplace Learning, 17(7), 436-451. http://dx.doi.org/10.1108/13665620510620025

Vorhies, D. W., Harker, M., \& Rao, C. P. (1999). The capabilities and performance advantages of market-driven firms. European Journal of Marketing, 33(11/12), 1171-1202. http://dx.doi.org/10.1108/03090569910292339

Weick, K. E., \& Roberts, K. H. (1993). Collective mind in organizations: heedful interrelating on flight decks. Administrative Science Quarterly, 38(3), 357-81. http://dx.doi.org/10.2307/2393372

Wright, P., Cardner, T., Moynihan, L., \& Allen, M. (2005). The relationship between HR practices and firm performance: Examining causal order. Personnel Psychology, 58, 409-446. http://dx.doi.org/10.1111/j.1744-6570.2005.00487.x

Wright, P. M., McCormick, B., \& Sherman, W. S. (1998). Strategy, core competence, and HR involvement as determinants of HR effectiveness and refinery performance. Human Resource Management, 37(1), 17-29. http://dx.doi.org/10.1002/(SICI)1099-050X(199821)37:1<17::AID-HRM3>3.0.CO;2-Y

Table 1. Results of testing hypothesis 1

\begin{tabular}{|l|l|l|l|l|l|l|}
\hline $\begin{array}{l}\text { Personal } \\
\text { data }\end{array}$ & Gender & Age & Education & Working experience & Monthly income & Task responsibility \\
\hline HR competencies & $\mathrm{t}=-2.99$ & $\mathrm{~F}=16.81$ & $\mathrm{~F}=12.02$ & $\mathrm{~F}=3.61$ & $\mathrm{~F}=6.66$ & $\mathrm{t}=1.99$ \\
& $\mathrm{p}$-value $0.003^{*}$ & $\mathrm{p}$-value $0.000^{*}$ & $\mathrm{p}$-value $0.000^{*}$ & $\mathrm{p}$-value $0.007^{*}$ & $\mathrm{p}$-value $0.000^{*}$ & $\begin{array}{l}\mathrm{p} \text {-value } \\
0.047^{*}\end{array}$ \\
\hline
\end{tabular}

Table 2. Results of testing hypothesis 2

\begin{tabular}{|l|l|l|l|l|}
\hline Organizational characteristics & Authorized capital & Nationality & Number of workers & Type of main product \\
\hline HR competencies & $\mathrm{F}=5.94$ & Brown-Forsythe $=1.06$ & $\mathrm{~F}=3.85$ & $\mathrm{~F}=3.57$ \\
& p-value & p-value 0.352 & p-value & p-value \\
& $0.003 *$ & & $0.022^{*}$ & $0.007 *$ \\
\hline
\end{tabular}

Table 3. Results of testing hypothesis 3

\begin{tabular}{|l|l|l|l|l|l|l|}
\hline Personal data & \multicolumn{1}{|c|}{ Gender } & \multicolumn{1}{|c|}{ Age } & \multicolumn{1}{|c|}{ Education } & \multicolumn{1}{|c|}{$\begin{array}{c}\text { Working } \\
\text { experience }\end{array}$} & \multicolumn{1}{|c|}{$\begin{array}{c}\text { Monthly } \\
\text { income }\end{array}$} & \multicolumn{1}{c|}{ Task responsibility } \\
\hline IT competencies & $\mathrm{t}=-2.99$ & $\mathrm{~F}=15.39$ & $\mathrm{~F}=9.65$ & $\mathrm{~F}=16.81$ & $\mathrm{~F}=13.67$ & $\mathrm{t}=1.09$ \\
& $\mathrm{p}$-value & $\mathrm{p}$-value & $\mathrm{p}$-value & $\mathrm{p}$-value & $\mathrm{p}$-value & $\begin{array}{l}\mathrm{p} \text {-value } \\
0.276\end{array}$ \\
& $0.003^{*}$ & $0.000^{*}$ & $0.000^{*}$ & 0.443 & $0.000^{*}$ & 0.27 \\
\hline
\end{tabular}

Table 4. Results of testing hypothesis 4

\begin{tabular}{|l|l|l|l|l|}
\hline Organizational characteristics & Authorized capital & Nationality & Number of workers & Type of main product \\
\hline IT competencies & $\mathrm{F}=0.34$ & Brown-Forsythe $=1.53$ & $\begin{array}{l}\text { Brown-Forsythe }=1.08 \\
\text { p-value } 0.834\end{array}$ & $\begin{array}{l}\mathrm{F}=4.14 \\
\text { p-value } 0.003^{*}\end{array}$ \\
\hline
\end{tabular}


Table 5. Results of testing hypothesis 5

\begin{tabular}{|c|c|c|c|c|c|c|}
\hline $\begin{array}{l}\text { Personal } \\
\text { data }\end{array}$ & Gender & Age & Education & Working experience & $\begin{array}{l}\text { Monthly } \\
\text { income }\end{array}$ & $\begin{array}{l}\text { Task } \\
\text { responsibility }\end{array}$ \\
\hline $\begin{array}{l}\text { Market knowledge } \\
\text { competencies }\end{array}$ & $\begin{array}{l}\mathrm{t}=-3.24 \\
\mathrm{p} \text {-value } \\
0.001 *\end{array}$ & $\begin{array}{l}\mathrm{F}=3.16 \\
\mathrm{p} \text {-value } \\
0.025^{*}\end{array}$ & $\begin{array}{l}F=2.05 \\
p \text {-value } \\
0.130\end{array}$ & $\begin{array}{l}\text { Brown-Forsythe = } \\
3.18 \\
\text { p-value } 0.014^{*}\end{array}$ & $\begin{array}{l}\mathrm{F}=16.43 \\
\mathrm{p} \text {-value } 0.000^{*}\end{array}$ & $\begin{array}{l}\mathrm{t}=0.70 \\
\mathrm{p} \text {-value } 0.479\end{array}$ \\
\hline
\end{tabular}

Table 6. Results of testing hypothesis 6

\begin{tabular}{|l|l|l|l|l|}
\hline Organizational characteristics & Authorized capital & Nationality & Number of workers & Type of main product \\
\hline Market knowledge competencies & $\mathrm{F}=2.69$ & $\mathrm{~F}=4.43$ & Brown-Forsythe $=2.78$ & $\mathrm{~F}=0.33$ \\
& $\mathrm{p}$-value 0.069 & $\mathrm{p}$-value $0.012 *$ & $\mathrm{p}$-value 0.063 & $\mathrm{p}$-value 0.853 \\
\hline
\end{tabular}

Table 7. Results of testing hypothesis 7 the influence of HR competencies, IT competencies, and market knowledge competencies on HR performance

\begin{tabular}{|l|l|l|l|l|l|l|l|}
\hline \multirow{2}{*}{} & \multicolumn{2}{|l|}{ Unstandardized Coefficients } & Standardized Coefficients & & \multirow{2}{*}{ Tolerance } & VIF \\
\cline { 2 - 7 } & $\mathrm{B}$ & Std. Error & Beta & t & P-value & & \\
\hline (Constant) & 1.732 & .120 & & 14.40 & $.000^{*}$ & & \\
\hline HR competencies & .399 & .041 & .501 & 9.62 & $.000^{*}$ & 0.51 & 1.92 \\
\hline Market knowledge competencies & .077 & .032 & .126 & 2.42 & $.016^{*}$ & 0.48 & 2.08 \\
\hline IT competencies & 0.055 & 0.46 & 0.079 & 1.187 & 0.236 & 0.39 & 2.50 \\
\hline
\end{tabular}

$\mathrm{R}=0.585, \mathrm{R}^{2}=0.342$ or $34.2 \%$, Adjusted $\mathrm{R}^{2}=0.338$, Durbin-Watson $=1.858, \mathrm{~F}=96.29$, P-value $=0.000 *$

Table 8. Results of testing hypothesis 8 the influence of HR competencies, IT competencies, and market knowledge competencies on organizational performance

\begin{tabular}{|l|l|l|l|l|l|l|l|}
\hline & Unstandardized Coefficients & Standardized Coefficients & & \multirow{3}{*}{ Tolerance } & VIF \\
\cline { 2 - 8 } & $\mathrm{B}$ & Std. Error & Beta & $\mathrm{t}$ & P-value & & \\
\hline (Constant) & 1.327 & .230 & & 5.78 & $.000^{*}$ & & \\
\hline Market knowledge competencies & .397 & .061 & .501 & 6.51 & $.000^{*}$ & 0.04 & 2.08 \\
\hline HR competencies & .176 & .079 & .127 & 2.21 & $.027^{*}$ & 0.51 & 1.92 \\
\hline
\end{tabular}

$\mathrm{R}=0.485, \mathrm{R}^{2}=0.210$ or $21.0 \%$, Adjusted $\mathrm{R}^{2}=0.205$, Durbin-Watson $=1.817, \mathrm{~F}=49.22\left(\mathrm{P}\right.$-value $\left.=0.000^{*}\right)$ 


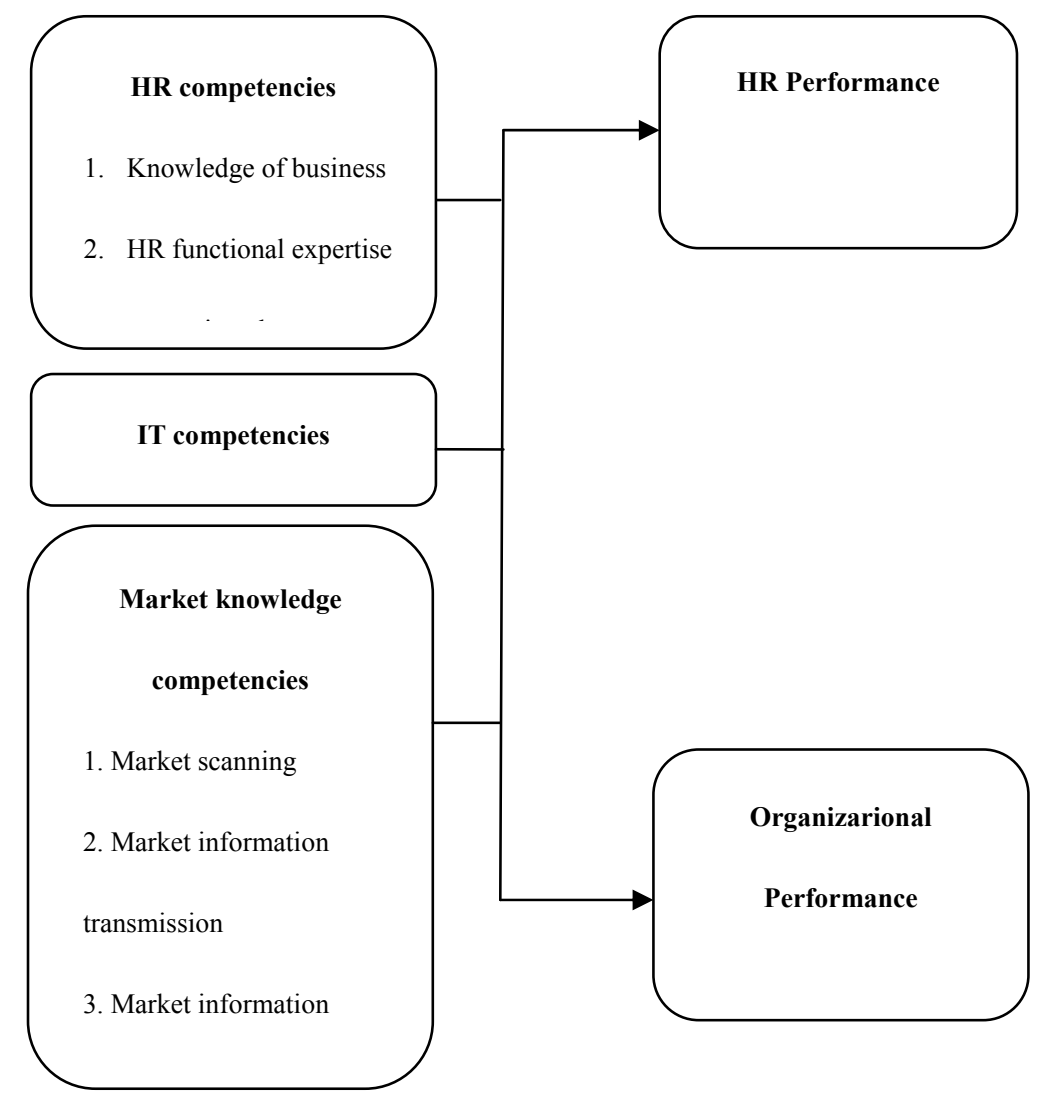

Figure 1. Conceptual Framework 